\title{
Attitudes of the nurses working in pediatric clinics towards children's rights
}

\section{Pediatri Kliniklerinde Çalışan Hemşirelerin Çocuk Haklarına Yönelik Tutumları}

\author{
IIllknur Yildız', Fatma Tok Yildız ${ }^{1}$
}

${ }^{1}$ Department of Nursing, Sivas Cumhuriyet University, Faculty of Health Sciences, Sivas, Turke

Corresponding author: İlknur Yildı, Ph.D., Department of Nursing, Sivas Cumhuriyet University, Faculty of Health Sciences, Sivas, Turkey

E-mail: ilknuryildiz@yahoo.com.tr

Received/Accepted: November 07, 2018 /June 29, 2019

Conflict of interest: There is not a conflict of interest.

\section{SUMMARY}

Objective: Pediatric nurses have significant responsibilities in adopting and implementation of the children's rights. This study was conducted to determine the attitudes of nurses working in pediatric service towards children's rights.

Method: The study was carried out with 104 nurses working in the pediatric services of a university hospital and state hospital and agreeing to participate in the research. The data of the study were gathered with Descriptive Information Form and Questionnaire for Measuring Attitudes towards Children's Rights. Descriptive statistics, Mann-Whitney U test, Kruskal-Wallis, and correlation analysis were used in the analysis of data.

Results: The average age of the nurses in the study is $32.10 \pm 7.69,97.1 \%$ are female, $62.5 \%$ have a bachelor's degree, $59.6 \%$ are married, and $51 \%$ have children. The work experience of $57.7 \%$ of the nurses and the experience of $80.8 \%$ of those in the pediatric clinic range from 0 to 10 years. Of pediatric nurses, $77.9 \%$ stated that they heard about the Convention on the Rights of the Child, $52.9 \%$ said they have no idea as to whether our country has signed this convention, and $96.2 \%$ reported they pay attention to the children's rights and they have to take active role on the children's rights. The Questionnaire for Measuring Attitudes towards Children's Rights average scores of the nurses are 27.16 \pm 5.34. When Questionnaire for Measuring Attitudes towards Children's Rights average scores was examined according to the descriptive characteristics of the nurses, the difference between them was found to be statistically insignificant $(\mathrm{p}>0.05)$.

Conclusions: It might be concluded that the attitudes of pediatric nurses towards children's rights are positive. This study contributes to the nurses working in pediatric clinics to pay attention to children's rights in the practices of treatment and care for children.

Keywords: Pediatric,nurse,children's rights, attitude

*This study was presented as an oral presentation at the 5th International 16th National Nursing Congress held in Ankara/Turkey between November 5-7, 2017.
(iD) İlknur Yıldız
(D) Fatma Tok Yildiz

ORCID IDs of the authors: İ.Y. 0000-0002-2574-7018 F.T.Y. 0000-0001-7543-2076 
Amaç: Pediatri hemşirelerinin çocuk haklarının kabulü ve uygulanmasında önemli sorumlulukları bulunmaktadır. Bu çalışma, pediatri servisinde çalışan hemşirelerin çocuk haklarına ilişkin tutumlarını belirlemek amacıyla yapılmışır. Yöntem: Çalışma bir üniversite ve bir devlet hastanesinin pediatri servislerinde çalışan ve araştırmaya katılmayı kabul eden 104 hemşire ile yapılmıştır. Araştırmanın verileri Tanıtıcı Bilgi Formu ve Çocuk Haklarına İliş̧in Tutum Ölçeği (ÇHTÖ) ile toplanmıştır. Verilerin analizinde tanımlayıcı istatistikler, Mann Whitney U testi, Kruskal-Wallis ve korelasyon analizi kullanılmıştır.

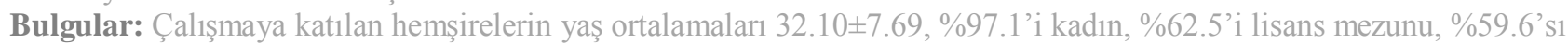
evli ve \%51.'i çocuk sahibidir. Hemșirelerin \%57.7'sinin meslekte çalıșma y1lı, \%80.8'inin ise pediatri kliniğinde çalıșma yılı 0-10 yıl arasında değișmektedir. Pediatri hemşirelerinin \%77.9'u çocuk hakları sözleșmesini duyduğunu, \%52.9’u ülkemizin bu sözleşmeyi imzalayıp imzalamadığı konusunda fikrinin olmadığııı, \%96.2'si de çalışırken çocuk haklarını gözettiğini ve çocuk hakları konusunda aktif rol alması gerektiğini belirtmiş̧tir. Hemşirelerin ÇHTÖ puan ortalaması $27.16 \pm 5.34$ 'dür. Hemşirelerin tanıtıcı özelliklerine göre ÇHTÖ puan ortalamaları incelendiğinde aradaki farkın istatistiksel olarak anlamlı olmadığı belirlenmiş̧ir ( $>0.05)$.

Sonuç: Pediatri kliniğinde çalışan hemşirelerinin çocuk haklarına yönelik tutumlarının olumlu olduğu söylenebilir. Bu çalışma pediatri kliniğinde çalışan hemşirelerin çocuklara yönelik tedavi ve bakım uygulamalarında çocuk haklarını gözetmelerine katkı sağlayabilir.

Anahtarsözcükler: pediatri, hemşire, çocuk hakları,tutum

\section{INTRODUCTION}

The "right" is the authorization of doing something or of demanding others to do something and to behave in a specific way ${ }^{1}$. An advocate is a person who assumes the role of guiding to take a right, claiming and protecting the others' rights, and thereby carrying the necessary conditions determined by law. Children are more vulnerable because they are different from adults in biological, psychological, and social aspects ${ }^{2,3}$. After the First World War, international organizations have been initiated by various organizations to protect children, taking into account the needs of children. As a result, the first international regulation on children's rights emerged in 1924. The United Nations declared the Declaration on the Rights of the Child in 1959 and the Convention on the Rights of the Child was adopted on 20 November 1989. In Turkey, this contract entered into force on 27 January $1995^{1,4}$ 6

Health care professionals working in the field of child health have important roles and responsibilities in the health care advocacy of children and families in the protection and implementation of children's rights ${ }^{7}$. Pediatric nurses fulfill the role of advocacy in making conscious choices by helping the children and their families ${ }^{6,8}$. It is the pediatric nurse's priority to look after the child's benefits, to give safe, quality care, to provide the right for a child to be free from all kinds of harmful factors and to observe this right in practice ${ }^{9}$. In the Nursing Law, Pediatric nurse is defined as a person who is responsible for promoting the healthy growth and development of children between 0 and 18 years of age in the family and society in terms of physical, cognitive, emotional and social aspects, for keeping them from contracting disease and maximizing their health, and for treatment, care and rehabilitation of the children when they are sick in accordance with universal child rights and professional nursing roles ${ }^{10}$. Accordingly, the Convention on the Rights of the Child guides pediatric nurses to ensure that each child receives optimal care. The articles in the Convention provide a framework for the principles and standards that can be used in the planning and implementation of health services for all children and youth ${ }^{9}$.

Every child has the right to receive care, and every pediatric nurse must maintain adequate care and professional competence to ensure the delivery of this right ${ }^{9}$. It has been determined that the studies conducted with health professionals ${ }^{11,12}$ to determine the attitudes of parents, teachers and teacher candidates ${ }^{13-15}$ towards child rights are limited in a study of health workers' attitudes towards children's rights, $81.1 \%$ of health professionals stated that health workers should take an active role in child rights, and 69\% stated that they were observing child rights while organizing their own work programs ${ }^{11}$. In a study conducted with nursing students, it was found that students generally showed a positive attitude towards child rights ${ }^{16}$. In a study conducted by pediatric nurses by Küçük Alemdar and Yılmaz (2017), pediatric nurses' attitudes towards child rights are positive, but they have not been informed about child rights.

Pediatric nurses, responsible for the care of a healthy/sick child, also have important responsibilities in the adoption and implementation of child rights. The positive 
attitude of pediatric nurses towards child rights will provide positive contributions to the health and development of children thought to be the future of society. In light of this information, this research was conducted to determine the attitudes of pediatric nurses to child rights and the effective factors.

\section{Research Questions}

- What are the attitudes of pediatric nurses towards children's rights?

- Are there any differences in attitudes towards children's rights of pediatric nurses' according to some sociodemographic and professional characteristics?

\section{MATERIAL AND METHODS}

This study was conducted as a cross-sectional to determine the attitudes of pediatric nurses to child rights between May and June 2017. The population of the study consists of 120 nurses working in a university and a state hospital province of Sivas. Since reaching the whole of the population was targeted in the study, no sample calculation was made. A total of 104 nurses were included in the survey because of some nurses' use of annual leave and their refusal to participate in the research at the time of the study. The data collection stage had one stage. The information form and scale were filled out by the nurses who were working in the pediatric clinics at their appropriate times. It took on average 10-15 minutes to fill out this form. The data of the research were collected through the Descriptive Information Form created by the researchers and the Children's Rights Attitude Scale.

\section{Descriptive Information Form}

The questionnaire includes questions about age, gender, marital status, years of work in the profession and in the pediatric clinic, and the status of getting information about child rights.

\section{Questionnaire for Measuring Attitudes towards Children's Rights}

The scale was developed by Karaman Kepenekçi (2006). There are 22 items on the scale regarding the vital, developmental, protection, and participation rights of children. There is no subdimension. The scale is of 5-point Likert type and has the options of "I Strongly Agree," "I Agree," "Neither Agree Nor Disagree," "I Disagree" and "I Strongly Disagree." 19 of the expressions in the scale are positive, while 3 are negative. Reactions given to negative statements $(2,14$ and 15) are scored in reverse. The lowest score to be taken from the scale is 22 , and the highest score is 110 , and high scores indicate negative attitude ${ }^{17}$.

\section{Ethical Consideration of the Study}

Before starting the investigation, Ethics Committee approval was first taken from the Ethics Committee of Cumhuriyet University Faculty of Medicine (No: 2017-04/22), and then written permissions were taken from the institutions. During the implementation period, nurses working in pediatric services and agreeing to participate in the study were included in the sampling. Written approvals were obtained from the nurses participating in the research by giving information about the purpose of study.

\section{Statistical Analysis}

For the analysis of the study, SPSS Statistics V22.0 (IBM Corporation, New York, USA) program was used. Percentage, mean and standard deviation from descriptive statistics were used, and Mann Whitney U test and Kruskal-Wallis tests from analytical statistics were used since parametric test assumptions were not met. The level of significance was accepted as $\mathrm{p}<0.05$.

\section{RESULTS}

The average age of the pediatric nurses is $32.10 \pm 7.69,97.1 \%$ are women, $62.5 \%$ have a bachelor's degree, $59.6 \%$ are married, and $51 \%$ have children. The work experience of $57.7 \%$ of the nurses and the experience of $80.8 \%$ of those in the pediatric clinic range from 0 to 10 years. Of pediatric nurses, $77.9 \%$ stated that they heard about the Convention on the Rights of the Child, $52.9 \%$ said they have no idea as to whether our country has signed this convention, and $96.2 \%$ reported they pay attention to the children's rights and they have to take active role on the children's rights (Table 1).

The Questionnaire for Measuring Attitudes towards Children's Rights average scores of the nurses are 27.16 \pm 5.34 . When scale average scores were examined according to the descriptive characteristics of the nurses, the difference between them was found to be statistically insignificant ( $p>0.05$ ) (Table 2). 
Table 1: The demographic characteristics of nurses $(n=104)$

\begin{tabular}{|c|c|c|}
\hline Descriptive Characteristics & $\mathbf{n}$ & $\%$ \\
\hline \multicolumn{3}{|l|}{ Gender } \\
\hline Female & 101 & 97.1 \\
\hline Male & 3 & 2.9 \\
\hline \multicolumn{3}{|l|}{ Education Level } \\
\hline Medical-Vocational School & 9 & 8.7 \\
\hline Associate's Degree & 17 & 16.3 \\
\hline Bachelor's Degree & 65 & 62.5 \\
\hline Postgraduate & 13 & 12.5 \\
\hline \multicolumn{3}{|l|}{ Marital Status } \\
\hline Married & 62 & 59.6 \\
\hline Single & 42 & 40.4 \\
\hline \multicolumn{3}{|l|}{ Having Children } \\
\hline Yes & 53 & 51.0 \\
\hline No & 51 & 49.0 \\
\hline \multicolumn{3}{|c|}{ Working year in the profession } \\
\hline $0-10$ years & 60 & 57.7 \\
\hline $11-20$ years & 27 & 26.0 \\
\hline $21-30$ years & 17 & 16.3 \\
\hline \multicolumn{3}{|c|}{ Working year in a pediatric clinic } \\
\hline $0-10$ years & 84 & 80.8 \\
\hline $11-20$ years & 16 & 15.4 \\
\hline $21-30$ years & 4 & 3.8 \\
\hline \multicolumn{3}{|c|}{ Hearing of the Convention on the Rights of the Children } \\
\hline Yes & 81 & 77.9 \\
\hline No & 23 & 22.1 \\
\hline \multicolumn{3}{|c|}{ Views on the children's rights in our country } \\
\hline Signed & 46 & 44.2 \\
\hline Not signed & 3 & 2.9 \\
\hline No idea & 55 & 52.9 \\
\hline \multicolumn{3}{|c|}{ To receive education on children's rights during undergraduate education } \\
\hline Yes & 54 & 51.9 \\
\hline No & 50 & 48.1 \\
\hline \multicolumn{3}{|c|}{ Considering children's rights in care } \\
\hline Yes & 100 & 96.2 \\
\hline No idea & 4 & 3.8 \\
\hline \multicolumn{3}{|c|}{ Do you think pediatric nurses should take an active role in children's rights? } \\
\hline Yes & 100 & 96.2 \\
\hline No idea & 4 & 3.8 \\
\hline
\end{tabular}


Table 2: Mean Scores of the Nurses for Children's Rights by Descriptive Characteristics

\begin{tabular}{|c|c|c|}
\hline Descriptive Characteristics & $\bar{X} \pm$ SD & Test and p-value \\
\hline \multicolumn{3}{|l|}{ Gender } \\
\hline Female & $27.08 \pm 5.35$ & \multirow{2}{*}{$p=0.28$} \\
\hline Male & $29.66 \pm 5.50$ & \\
\hline \multicolumn{3}{|l|}{ Education Level } \\
\hline Medical Vocational School & $27.00 \pm 5.74$ & \multirow{4}{*}{$p=0.93$} \\
\hline Associate's Degree & $26.52 \pm 4.01$ & \\
\hline Bachelor's Degree & $27.52 \pm 5.90$ & \\
\hline Postgraduate & $26.30 \pm 3.70$ & \\
\hline \multicolumn{3}{|l|}{ Marital Status } \\
\hline Married & $27.09 \pm 5.84$ & \multirow{2}{*}{$p=0.70$} \\
\hline Single & $27.26 \pm 4.58$ & \\
\hline \multicolumn{3}{|l|}{ Having Children } \\
\hline Yes & $26.88 \pm 6.00$ & \multirow{2}{*}{$p=1.21$} \\
\hline No & $27.45 \pm 4.61$ & \\
\hline \multicolumn{3}{|c|}{ Working year in the profession } \\
\hline $0-10$ years & $27.51 \pm 4.17$ & \multirow{3}{*}{$p=0.33$} \\
\hline $11-20$ years & $25.85 \pm 3.50$ & \\
\hline $21-30$ years & $28.00 \pm 8.82$ & \\
\hline \multicolumn{3}{|c|}{ Working year in a pediatric clinic } \\
\hline $0-10$ years & $27.60 \pm 5.60$ & \multirow{3}{*}{$p=0.11$} \\
\hline $11-20$ years & $25.12 \pm 3.18$ & \\
\hline $21-30$ years & $26.00 \pm 5.65$ & \\
\hline \multicolumn{3}{|c|}{ Hearing of the Convention on the Rights of the Children } \\
\hline Yes & $26.88 \pm 5.43$ & \multirow{2}{*}{$p=0.20$} \\
\hline No & $28.13 \pm 5.00$ & \\
\hline \multicolumn{3}{|c|}{ Views on the children's rights in our country } \\
\hline Signed & $27.19 \pm 6.07$ & \multirow{3}{*}{$p=0.63$} \\
\hline Not signed & $31.00 \pm 8.88$ & \\
\hline No idea & $26.92 \pm 4.46$ & \\
\hline \multicolumn{3}{|c|}{ To receive education on children's rights during undergraduate education } \\
\hline Yes & $27.11 \pm 5.83$ & \multirow{2}{*}{$p=0.25$} \\
\hline No & $27.22 \pm 4.82$ & \\
\hline \multicolumn{3}{|c|}{ Considering children's rights in care } \\
\hline Yes & $27.09 \pm 5.20$ & \multirow{2}{*}{$p=0.73$} \\
\hline No idea & $30.00 \pm 8.90$ & \\
\hline \multicolumn{3}{|c|}{ Do you think pediatric nurses should take an active role in children's rights? } \\
\hline Yes & $27.17 \pm 5.38$ & \multirow{2}{*}{$p=0.69$} \\
\hline No idea & $28.00 \pm 5.35$ & \\
\hline
\end{tabular}

\section{DISCUSSION}

The scoring average of nurses working at the pediatric service was $27.16 \pm 5.34$. This result is lower than the scoring average of Questionnaire for Measuring Attitudes towards Children's Rights $(36.19 \pm 10.19)$ in the study conducted by Küçük Alemdar and Yılmaz (2017) and indicates that attitudes are more positive. The positive attitudes of the nurses working in the pediatrics clinic towards children's rights may positively affect the satisfaction of the children and their families who are taking care and treatment.

It can be seen that gender did not significantly affect the score averages, but female nurses showed a more positive attitude toward children's rights. This may be due to the fact that the 
majority of the nurses participating in the study are women and that women are instinctively more concerned with children. In a study conducted on health professionals' attitudes towards children's rights, gender was not found to be effective on scale scores ${ }^{11}$.

Education level can affect attitudes and sensitivity towards children. It has been observed that the nurses who take postgraduate education show a more positive attitude, but the difference is not significant. This situation can be interpreted that with the postgraduate education, the point of view towards children's rights differs and the sensitivity increases. In addition, this result may be considered as an indication that the nurses who received graduate education reflect their knowledge in practice. Another study found that the education level of nurses working in the pediatric service did not affect the Questionnaire for Measuring Attitudes towards Children's Rights score averages ${ }^{12}$.

In the study, the marital status and having children were found not to affect the attitudes towards children's rights. In studies carried out to determine whether nurses love children, Tural Büyük et al. (2014) stated that the number of children in nurses did not affect their state of loving children, while Erdem \& Duyan (2011) noted that marital status and having children in pediatric nurses did not affect their state of loving children. Küçük Alemdar \&Yilmaz (2017) found that marital status and having children did not affect the score averages of Questionnaire for Measuring Attitudes towards Children's Rights. In a study conducted with health professionals, it was determined that having children did not affect the attitudes towards children's rights ${ }^{11}$. According to these results, it can be interpreted that marital status and having children are not an impressive factor in determining attitudes towards children's rights.

It was found that the majority of the nurses had a working year of 0 to 10 years in the profession and pediatric service, but this did not significantly affect the score averages. In a study conducted, it was found out that as the professional experience of health professionals increased, the state of hearing of the Convention on the Rights of the Children also increased, but the score averages of the children's rights scale were not significantly affected ${ }^{11}$. These findings obtained from our study and literature may be related to nurses' usage of career development and investigator roles in practice.
Hearing of the Convention on the Rights of the Children and being aware that our country has signed this convention have a direct impact on advocacy and paying attention to the children's rights. $77.9 \%$ of the nurses participating in the study stated that they heard of the Convention on the Rights of the Children, and $44.2 \%$ stated our country had signed this convention. In a study conducted with health professionals, only $9.9 \%$ out of 300 participants know that our country has signed the Convention on the Rights of the Children ${ }^{11}$. It was revealed that half of the nurses participating in the study $(51.9 \%)$ were informed about the children's rights. In their study conducted with 68 pediatric nurses, Küçük Alemdar \&Y1lmaz (2017) found that the majority of the nurses (79.4\%) did not have knowledge about the children's rights. This result may be considered as having heard of the rights of child rights, but limited in the use of information in our country. It can also be associated with the awareness of pediatric nurses in the field.

Pediatric nurses protect and pay attention to the rights of the children and the family and help them to seek their rights when necessary in accordance with their advocacy roles ${ }^{8,9}$. In our study, $96.2 \%$ of the nurses working in pediatric service stated that they pay attention to the children's rights while working and that they should take an active role in children's rights. In a study, half of the health professionals (50.3\%) regarded themselves as inadequate in advocating for children's rights ${ }^{11}$. In another study, pediatricians were trained on child advocacy, and it was determined after the training that there was an increase in their knowledge of advocacy, ability to identify social resources in their perceptions and self-report of advocacy skills ${ }^{20}$. These results highlight the fact that health professionals working for and with children should have the necessary knowledge about children's rights in order to implement effective care and treatment.

\section{CONCLUSION}

In conclusion, it was determined that the majority of the pediatric nurses are women, about $3 / 4$ of them have heard of the Convention on the Rights of the Children, the majority of them pay attention to the children's rights while working and they think they should take an active role on children's rights. At the same time, it can be said that the attitudes of pediatric nurses towards children's rights are positive. In accordance with these results, it is suggested that nurses working in pediatric clinics should be informed about the 
policies regarding children's rights, the results of the study should be shared with the relevant institutions, and the research should be carried out in a larger sample.

\section{Limitations}

There are some limitations to this study. The results can be generalized to nurses working in the sampled pediatric clinic. In a larger sample, multicentered and multidisciplinary studies can be planned.

\section{REFERENCES}

1. Akyüz E. Child Law. Ankara, Pegem Akademi Yayınları, 2010. p.1-10

2. Avc1 K. Investigation of the nurses' approach to the solution of the ethical issues in pediatric area (Master Thesis). Ankara: Hacettepe University; 2007.

3. Özakar Akça S, Gözen D. Advocacy role of the pediatric nurse. FNJN Florence Nightingale Journal of Nursing 2013; 21(3): 213-218.

4. İnan A.N. Convention on children's rights. Ankara University Faculty of Law Journal 1995;1(4):768-769.

5. Akyüz E. The right of the child to education in light of the basic principles of the children's rights convention. National Education Journal 2001; 151:1-26.

6. Conk Z, Başbakkal Z, Yardımcı F. Child Health Overview. In: Conk Z, Başbakkal Z, Balyılmaz H, Bolışık B (eds). Pediatric Nursing. $1^{\text {st }}$ ed. Ankara, Akademisyen Tip Kitabevi, 2013;1-3.

7. Perrin JM. Advocacy and Child Health. Ambul Pediatr 2004; 4(4):267-8.

8. Ball JW, Bindler RC. Nurse's role in care of the child: hospital, community settings, and home. In: Ball JW, Bindler RC (eds). Pediatric Nursing Caring for Children, 4th ed. New Jersey, Pearson Education, 2008; 1-24.

9. Erdemir F. Child Care, Pediatric Nurses as Children's and Family Advocates. Child and Family Advocate. 4th National Pediatric Nursing Congress Book, 22-25 May 2013, Adiyaman.

10. Hemşirelik Yönetmeliğinde Değişiklik Yapılmasına Dair Yönetmelik https://www.saglik.gov.tr/TR,10526/hemsireli k-yonetmeliginde-degisiklik-yapilmasinadair-yonetmelik- html Accesed:7 December 2016.
11. Kurt G. The evaluation of pediatric healthcare according to the children's rights convention and the awareness and attitude of healthcare professionals on children rights in hospitals in Kirıkkale Province (Master Thesis). Kırıkkale: Kırıkkale University; 2012.

12. Küçük Alemdar D, Yılmaz G. Determining the attitudes of pediatric nurses towards children's rights. International 3. Forensic Nursing 2. Forensic Social Service 1. Congress of Forensic Gerontology. Bozok University, 12-14 October 2017, Yozgat. Oral Presentation.

13. Casas F, Sapariti A, González M, Figuer C, Rostan C, Sadurni M, et.al. Children's rights from the point of view of children, their parents and their teachers: A comparative study between Catalonia (Spain) and II Molise (Italy). Int'l J Child Rts 2006;14: 1-75.

14. Leblebici H, Çeliköz N. Prospective teachers' attitudes towards children rights. IJSSES 2017; 3(1): 307-318.

15. Merey Z. Social studies pre-service teachers' attitudes towards children's rights. Journal of Theory and Practice in Education 2013; 9(3): 243-253.

16. Aldemir EY. Nursing students' attitudes concerning the determination of children's rights (Master Thesis). İstanbul: İstanbul Bilim University; 2014.

17. Karaman Kepenekçi Y. A study of university students' attitudes towards children's rights in Turkey. Int'1 J Child Rts 2006;14: 307-319.

18. Tural Büyük E, Rızalar S, Güdek Seferoğlu E, Oğuzhan H. Analysing liking of children and parenting attitudes of nurses working in pediatric and adult clinics. The Journal of Pediatric Research 2014;1(3):130-7

19. Erdem Y, Duyan V. A determination of the factors that affect the level of pediatric nurses' liking of children. Turk J Med Sci. 2011; 41 (2): 295-305.

20. Roth EJ, Barreto P, Sherritt L, Palfrey JS, Risko W, Knight JR. A new, experiential curriculum in child advocacy for pediatric residents. Ambul Pediatr 2004;4(5):418-423. 